\title{
STRESS AKADEMIK DAN COPING MAHASISWA MENGHADAPI PEMBELAJARAN ONLINE DI MASA PANDEMI COVID-19
}

\author{
Amallia Putri, Yuline \\ Program Studi Bimbingan dan Konseling, Universitas Tanjungpura \\ Amalliaputri@ fkip.untan.ac.id
}

\begin{abstract}
ABSTRAK
Studi literatur ini disusun dengan tujuan untuk memaparkan kondisi stress akademik serta coping yang dilakukan mahasiswa mengatasi stress akademik dalam pembelajaran online dimasa pandemi covid- 19 . Dalam menelaah beberapa jurnal mengenai stress akademik mahasiswa, diperoleh bahwa pandemi serta perubahan yang terjadi pada proses pembelajaran membuat meningkatnya stress akademik mahasiswa. Banyak permasalahan yang bermunculan akibat dari meningkatnya stress akademik. Untuk mengatasinya mahasiswa perlu melakukan strategi coping stress untuk mengurangi perasaan stress yang terjadi. Coping dimaknai sebagai sebuah usaha individu untuk dapat mengatasi stress yang menghampirinya melalui perubahan kognitif atau perilaku agar memperoleh perasaan aman pada dirinya. Coping stress ini dapat dilakukan dengan dua cara, yaitu: 1) Problem focused copping yang mengubah atau menghilangkan stressor dan mengurangi dampak stress melalui tindakan individu itu sendiri, dan 2) Emotional focused coping yaitu dengan mengubah cara individu secara emosional bereaksi terhadap penyebab stress. Dengan informasi mengenai pengelolaan stress akademik melalui coping stress mahasiswa diharapkan lebih peduli dan sadar sehingga dapat mengurangi tekanan psikologis dalam menghadapi pembelajaran online dimasa pandemi covid-19.
\end{abstract}

Kata Kunci: Stress Akademik; Coping Stress; Pembelajaran Online; Pandemi Covid-19

\begin{abstract}
This literature study was compiled with the aim of explaining the conditions of academic stress and the coping done by students to overcome academic stress in online learning during the covid-19 pandemic. In reviewing several journals regarding student academic stress, it was found that the pandemic and changes that occurred in the learning process had increased student academic stress. Many problems arise as a result of increased academic stress. To overcome this, students need to do stress coping strategies to reduce feelings of stress that occur. Coping is interpreted as an individual's effort to be able to overcome the stress that comes to him through cognitive or behavioral changes in order to gain a feeling of security in himself. Coping stress can be done in two ways, namely: 1) Problem focused coping that changes or eliminates stressors and reduces the impact of stress through the individual's own actions, and 2) Emotional focused coping, namely by changing the way individuals emotionally react to stressors. With information on managing academic stress through coping with stress, students are expected to be more concerned and aware so that they can reduce psychological pressure in dealing with online learning during the COVID-19 pandemic.
\end{abstract}

Keywords: Academic Stress; Copping stress; Online Learning; Covid-19 pandemic

Dipublikasikan Oleh :

UPT Publikasi dan Pengelolaan Jurnal

Universitas Islam Kalimantan Muhammad Arsyad Al-Banjari Banjarmasin 


\section{PENDAHULUAN}

Diawal tahun 2020 penyebaran virus covid-19 banyak menimbulkan dampak dalam berbagai aspek. Dampak yang ditimbulkan bukan hanya dari aspek kesehatan namun juga dalam aspek ekonomi, sosial, politik, psikologis bahkan pendidikan. Dampak sosial budaya salah satunya menunjukkan tingkat perceraian yang tinggi, interaksi sosial yang terbatas, serta pengaruh sosial pada perempuan dan anak (Yanuarita \& Haryati, 2021). Selain itu, tentunya pada sektor ekonomi pendapatan mengalami penurunan, lapangan pekerjaan menjadi terbatas, pengeluaran menjadi lebih besar (Sayuti \& Hidayati, 2020).

Seluruh aktifitas dalam masa pandemi dibatasi, hal ini juga terjadi dalam dunia pendidikan dengan diberlakukannya kebijakan Pembelajaran Jarak Jauh (PJJ) untuk semua jenjang pendidikan. Upaya ini tentunya dilakukan pemerintah sebagai salah satu cara menekan angka penyebaran Covid-19 yang terus meningkat. Meskipun dalam prakteknya menimbulkan pro dan kontra dalam kalangan masyarakat terkait dengan perubahan sistem pembelajaran dengan sistem daring yang juga memiliki dampak positif dan negative.

Pembelajaran jarak jauh merupakan alternatif yang dilakukan saat ini oleh banyak universitas. Perubahan metode belajar ini merupakan hal yang harus dilakukan agar roda pendidikan tetap berjalan, karena Universitas tetap harus menjalankan proses belajar mengajar dimasa pandemic covid-19. Pembelajaran jarak jauh menjadi tantangan bagi universitas dalam melaksanakan Pendidikan untuk mencapai tujuan Pendidikan itu sendiri (Sari, 2020). Kebijakan sistem pembelajaran jarak jauh (PJJ) atau daring memiliki berbagai dampak baik bagi pendidik maupun bagi peserta didiknya. Karena perubahan metode belajar yang terjadi cendrung berlangsung dengan sangat cepat sehingga adaptasi yang dilakukan membuat berbagai pihak merasa kesulitan dan belum siap dalam menyesuaikan diri terhadap teknologi saat melakukan pembelajaran online.

Selain dalam hal adaptasi metode pembelajaran, dalam pelaksanaannya pula banyak mahasiswa yang merasa tertekan karena tugas yang diberikan saat pembelajaran daring lebih banyak dari biasanya saat melakukan pembelajaran tatap muka dikampus. Belum lagi jika dilihat dari segi sarana dan prasana, tidak semua mahasiswa memiliki fasilitas baik dari segi media maupun jaringan internet untuk pembelajaran online. Penyesuaian terus dilakukan baik dari mahasiswa maupun dari tenaga pendidik dalam mengikuti perubahan yang terjadi dimasa pandemic ini. Namun, hal ini sering kali membuat mereka tertekan dan mengalami kebingungan. Perubahan pembelajaran ini membuat psikologis mahasiswa menjadi terganggu dan cendrung mengalami stress akademik selama mengikuti perkuliahan online (Fitriasari dkk, 2020). Menurut Barseli dkk (2017) Stres akademik adalah keadaan ketika seorang individu tidak dapat menghadapi tuntutan akademik serta menganggap tuntutan tersebut sebagai gangguan. Sementara itu Alvin (dalam Eryanti, 2012) menjelaskan bahwa stres akademik merupakan tekanan yang terjadi pada diri mahasiswa yang disebabkan oleh adanya persaingan ataupun tuntutan akademik. Untuk itu penting sekali memperhatikan kesehatan mental dan mengelolanya dalam keadaan sekarang sehingga tidak berpengaruh negative terhadap proses kehidupan yang sedang dijalani.

Stress yang dialami oleh mahasiswa dapat berpengaruh terhadap hasil belajarnya (Fitriasari dkk, 2020). Banyak masalah psikologis yang bermunculan dalam diri mahasiswa seperti cemas, stress, dan depresi. Hal ini didukung oleh penelitian yang dilakukan oleh Teguh dkk (2020) yang mengungkapkan dalam situasi pandemic Covid-19 memiliki dampak pada kesehatan mental mahasiswa seperti cemas terhadap nilai dan kelulusan studi yang mengakibatkan timbulnya stress akademik. Mahasiswa membutuhkan wadah untuk mereka melakukan konsultasi terhadap kecemasan yang mereka rasakan dalam kaitannya dengan meningkatkan kesadaran akan kesehatan mental diri mereka. Selama perkuliahan tatap muka pengerjaan tugas dapat dilakukan dengan diskusi dalam pertemuan kelompok langsung, namun selama pandemic pertemuan tatap muka dibatasi dan pengerjaan tugas dan diskusi dilakukan secara online dan hal tersebut juga menjadi salah satu faktor penyebab permasalahan mahasiswa juga. Sebagai mana yang disampaikan oleh Kartika (2020) bahwa berbagai penyebab dari masalah psikologis karena sulitnya tugas perkuliahan dan pengerjaan tugas kelompok, atmosfir pembelajaran yang tidak kondusif, kesulitan memahami materi perkuliahan karena tidak didapatkan secara langsung, jaringan yang tidak selalu baik dan seringkali terkendala, kejenuhan pembelajaran daring karena tidak dapat bertemu dengan rekan sesama mahasiswa dan tidak bisa melakukan aktifitas sebagaimana biasanya, serta berbagai perubahan yang terjadi dalam dinamika lingkungan keluarga di masa pandemi. 
Pola kehidupan kampus yang awalnya didominasi oleh kegiatan tatap muka di bangku perguruan tinggi berubah dimana mereka harus melakukan perkuliahan didominasi dengan metode pembelajaran online. Tentunya perubahan ini membawa dampak bagi mahasiswa. Penelitian yang dilakukan oleh Sari (2020) mengungkapkan sebanyak 38,57\% mahasiswa mengalami stress sedang, 32, $86 \%$ mengalami stress ringan dan 28,57\% mengalami stress berat. Menurut Hanifah et al (2020) Dampak stress pada mahasiswa dapat dikurangi dengan pemilihan coping yang efektif. Coping merupakan suatu upaya baik yang berupa perilaku atau mental untuk dapat mentoleransi atau meminimalisir suatu keadaan yang penuh akan tekanan. Dengan perkataan lain, coping ini dapat dimaknai sebagai sebuah usaha individu untuk dapat mengatasi stress yang menghampirinya melalui perubahan kognitif atau perilaku agar memperoleh perasaan aman pada dirinya. Strategi coping sendiri terbagi menjadi dua, yaitu : 1) problem solving coping dimana seorang individu berusaha melakukan penyelesaian masalah dengan menghilangkan suatu keadaan yang menimbulkan stress dan 2) emotion focused coping dimana seseorang individu berusaha untuk mengelola emosinya agar dapat menyesuaikan diri dengan dampak yang ditimbulkan dari suatu keadaan yang menyebabkan stress (Agustiningsih, 2019)

Berdasarkan beberapa studi literature diatas mengungkapkan bahwa perubahan ini bukan hanya berpengaruh pada perubahan metode pembelajaran yang dilakukan namun juga sangat berpengaruh terhadap tingkat stress mahasiswa. Artikel ini dibuat oleh penulis atas ketertarikan akan munculnya stress akademik dan pentingnya coping stress akademik untuk memaksimalkan proses pembelajaran online, serta artikel ini dapat memberikan informasi mengenai pengelolaan stress akademik melalui coping stress agar mahasiswa lebih peduli dan sadar sehingga harapannya dapat mengurangi tekanan psikologis dalam menghadapi pembelajaran online dimasa pandemi covid-19.

\section{METODE}

Penelitian ini menggunakan metode Literature Review. Istilah lain yang biasa digunakan adalah survei literatur, studi literatur, studi teori, landasan teori, dan kajian teori. Literature Review adalah penelitian yang sumber dan pengumpulan datanya dengan cara mengambil data kepustakaan, membaca, mencatat, dan mengolah bahan penelitian serta melihat dan menganalisis hasil riset tertentu.

\section{PEMBAHASAN}

Semua kegiatan belajar mengajar diseluruh jenjang pendidikan dialihkan dengan metode online atau dalam jaringan sejak dikeluarkan surat edaran mendikbud nomor 36962/ MPK.A/ HK/ 2020 hal ini dilakukan sebagai upaya pencegahan terhadap perkembangan dan penyebaran Coronavirus disease (Covid-19). Sekolah merealisasikannya dengan menutup proses pembelajaran luring dan berganti dengan metode daring (dalam jaringan) untuk mengantisipasi virus covid-19. Namun pada kenyataan implementasinya dirasakan masih belum maksimal yang ditunjukkan dengan masih terdapat ketidaksiapan dikalangan pendidik dalam beradaptasi dengan iklim digital (Charismiadji, 2020).

Dalam masa pandemic banyak kendalakendala yang dihadapi oleh mahasiswa. Mahasiswa harus mampu menyelesaikan berbagai tuntutan akademik yang menyebabkan mereka mengalami stress akademik. Mahasiswa yang tidak mampu beradaptasi pada keadaan tersebut akan membuat mereka masuk dalam keadaan stress. Selanjutnya stress yang dialami akan berpengaruh pada banyak aspek dalam dirinya yaitu pada aspek fisik dan aspek psikologis yang pada akhirnya mengakibatkan terganggunya proses belajar. Melihat berbagai dampak negatif yang dapat ditimbulkan maka dirasakan mahasiswa membutuhkan kemampuan coping.

\section{Stress Akademik dalam Pembelajaran Online dimasa Pandemi Covid-19}

Mahasiswa menjadi kurang optimal dalam mengikuti pembelajaran online karena merasa stress akibat tuntutan untuk beradaptasi dengan segala tantangan pada perubahan yang terjadi dimasa pandemi. Pembelajaran online sendiri adalah aktivitas belajar mengajar dengan menggunakan teknologi sehingga pendidik/guru, dosen, siswa, mahasiswa maupun orang tua peserta didik, berinteraksi melalui teknologi dengan berbagai platfoam. Memanfaatkan tekhnologi di era globalisasi dapat dimaksimalkan dalam keadaan pandemi seperti sekarang ini. Teknologi menjadi salah satu cara untuk tetap menjaga keberlangsungan sistem pendidikan yang mengharuskan proses pembelajaran dirumah saja. Harusnya sistem pembelajaran online bisa lebih mempermudah

Dipublikasikan Oleh : 
peserta didik untuk dapat mengakses bahan ajar, dan banyak platform yang dapat diakses melalui jaringan internet. Namun, nyatanya masih banyak faktor yang menyebabkan perubahan metode belajar ini menjadi tidak maksimal dan malah membuat stress peserta didik.

Stres akademik dimaknai sebagai keadaan yang mana seseorang menghadapi kesulitan dan tidak dapat menghadapi tuntutan akademik dan menganggap tuntutan akademik yang diterima sebagai gangguan (Barseli, dkk, 2017). Sementara itu Alvin (dalam Eryanti, 2012) menjelaskan bahwa stres akademik adalah suatu tekanan yang terjadi pada individu yang disebabkan karena adanya persaingan ataupun tuntutan akademik. Artinya dapat dimaknai sederhana bahwa stress merupakan sebuah tanggapan seseorang, dengan ancaman terhadap suatu perubahan di lingkungannya yang dirasakan menganggu dan mengakibatkan dirinya terancam, ancaman tersebut dapat berupa finansial, emosional, mental dan sosial. Menurut Goff. A.M. (2011), peningkatan stress akademik dapat berpengaruh terhadap indeks prestasi karena menurunkan kemampuan akademik.

Masalah yang muncul dalam pembelajaran daring ada banyak bentuknya. Selain terkait msalah teknologi, namun juga pada beban pada mata kuliah yang meningkat. Mahasiswa yang terbiasa dengan pembelajaran tatap muka secara offline harus mengadaptasi diri mereka ke dalam pembelajaran jarak jauh secara online. Perubahan ini tentunya memberikan dampak terhadap mahasiswa. Dampak yang ditimbulkan dapat berupa stress akademik. Aji (2020) menemukan fakta bahwa selama pembelajaran daring ada banyak permasalahan yang terjadi yang dapat menjadi penghambat keberhasilan pencapaian tujuan dari pembelajaran yaitu :1) Adanya keterbatasan penggunaan Teknologi Informasi oleh pendidik dan peserta didik; 2) Sarana dan prasarana kurang memadai; 3) Akses internet terhambat; 4) Kurangnya penyediaan anggaran.

Berdasarkan penelitian yang dilakukan Sari (2020) mengungkapkan bahwa sebagian besar mahasiswa mengalami stress sedang, yaitu sebanyak $38,57 \%$, selanjutnya mengalami stress berat sebanyak $28,57 \%$, dan stress ringan sebanyak 32,86\%. Kekhawatiran akan tertular virus covid-19 dan kesulitan dalam memahami materi merupakan stressor yang paling menyebabkan stress. Pembelajaran daring dirasakan masih membingungkan dari sisi implikasinya. Ada banyak mahasiswa yang mengeluhkan tugas yang banyak namun materi yang diberikan kurang sehingga mereka merasa kewalahan dalam mengikuti proses pembelajaran online. Pembelajaran daring membutuhkan adaptasi dan usaha terus menerus agar dapat berjalan dengan baik. Seperti pemahaman materi yang disampaikan dari video atau berupa tulisan bahkan melalui live streaming (Sari, 2020). Adaptasi dan modifikasi metode pembelajaran online sebaiknya terus dilakukan sebab banyak keluhan akan kebosanan yang dirasakan mahasiswa akibat pembelajaran online yang terkesan monoton (Amany, 2020).

Simbolon (2015) mengungkapkan bahwa tuntutan kehidupan kampus dapat menimbulkan stress akademik seperti tekanan mental dan emosional, sumbernya dapat berupa tugas yang terlalu banyak, keadaan yang monoton, ketidakjelasan, deadline tugas kuliah, merasa diacuhkan dan tidak dihargai, aturan yang membingungkan (Davidson dalam Purwati, 2012). Setiap individu tentunya berbeda dalam menanggapi keadaan ini, tingkatan stress akademiknyapun berbeda dari yang berat sampai yang ringan. Tingkat stresss akademik yang berat dapat menimbulkan penurunan kemampuan akademik yang berpengaruh juga terhadap indeks prestasi (Goff, 2011). Menurut hasil penelitian Maia et al (2020) menunjukkan para siswa yang dievaluasi selama pandemi covid-19 memperlihatkan tingkat yang jauh lebih tinggi dalam hal kecemasan, depresi, dan stress, dibandingkan dengan para siswa di masa-masa normal. Yang dalam artiannya hasil menunjukkan bahwa pandemi memberikan efek psikologis negatif pada siswa.

Masalah-masalah yang dialami mahasiswa, jika tidak segera ditangani dapat menimbulkan masalah psikologis yang lebih serius seperti depresi. Dibutuhkannya pengelolaan atas keadaan yang membuat terganggu dengan strategi coping yang tepat agar individu terarah pada respon yang adaptif, sehingga dapat bertahan dan menghasilkan dampak positif berupa peningkatan upaya menjaga kesehatan mental. Setiap individu tentunya memiliki ketahanan atau tingkat stres yang berbeda, sehingga coping yang dilakukan pun berbeda-beda. Tujuan melakukan coping adalah untuk meminimalisir hal yang membahayakan dir dari situasi dan kondisi lingkungan, meningkatkan kemungkinan untuk pulih, Melakukan penyesuaian diri pada peristiwa negatif yang dijumpai, menyeimbangkan keadaan emosional dalam diri, melakukan hubungan yang baik dengan orang 
lain, serta mempertahankan citra diri yang positif.

\section{Coping Stress dalam Pembelajaran Online dimasa Pandemi Covid-19}

Dalam pelaksanaan perkuliahan online banyak menemui kendala. Banyak mahasiswa yang megalami stress akademik karena tidak mampu melakukan adaptasi. Respon stress dapat berupa perilaku menghindari tugas menarik diri, sulit tidur, tidur terus, dan sulit makan (Wahyuni, 2017). Stress juga dapat dilihat dari sisi fisiologis, responnya berupa keringat, debaran jantung yang cepat, berkeringat dingin, sakit perut, pusing, cepat lelah. Sedangkan pada aspek psikologis, stres dapat berbentuk tidak berdaya, cemas, tidak termotivasi, merasa bersalah, bingung, frustasi, depresi, kecewa, takut, dan gelisah (Wahyuni, 2017).

Stress seharusnya dapat diatasi jika individu mau melakukan management stress atau coping stress. Coping stress sendiri dimaknai sebagai upaya dalam mengatasi atau mengelola stress. Coping didefinisikan sebagai suatu usaha untuk mengatur ketidaksesuaian perasaan antara tuntutan dan kemampuan yang orang itu miliki dalam situasi yang menekan, usaha coping bervariasi dan tidak semuanya berujung pada penyelesaian masalah (Sarafino, 2011). Selain itu, menurut Cicarelli (2015) Coping stress adalah strategi dalam psikologis atau perilaku yang dilakukan seseorang untuk meminimalkan, mentolerir, menguasai atau mengurangi efek dari sebuah stress.

Coping stress yang dilakukan dapat menimbulkan dampak positif dalam diri individu. Terdapat dua jenis coping stress menurut Folkman dan Lazarus (Ciccareli, 2015) Coping tersebut yaitu : 1) Problem focused coping, strategi coping jenis ini bertujuan untuk menghilangkan/ mengubah stressor itu sendiri atau ketika individu menghilangkan sumber stres dan mengurangi dampaknya melalui tindakan individu tersebut, sedangkan jenis berikutnya adalah 2) Emotional focused coping, strategi coping ini dengan mengubah cara seseorang merasakan atau secara emosional bereaksi terhadap stressor. Strategi ini mengurangi dampak emosional dari penyebab stress dan memungkinkannya untuk menyelesaikan masalah dengan lebih efektif.

Strategi problem-focused coping tujuannya agar dapat mengurangi tuntutan dalam keadaan yang menekan atau meningkatkan kemampuan dalam menghadapi masalah.
Folkman dan Lazarus (Safaria \& Saputra, 2009), Terdapat beberapa aspek problem focused coping. diantaranya : 1) Seeking informational support, yaitu berusaha untuk memperoleh informasi dari orang lain, seperti ke psikolog, dokter atau guru; 2) Confrontative coping, yaitu secara konkrit melakukan penyelesaian masalah; 3) Planful problem-solving, melakukan analisis terhadap keadaan yang menimbulkan masalah serta berusaha mencari solusi secara langsung terhadap masalah yang dihadapi.

Pada emotion-focused coping tujuannya adalah untuk mengontrol respon emosional yang terhadap situasi yang memberikan penekanan atau stressful. Individu dikatakan dapat mengatur respon emosionalnya melalui pendekatan behavioral dan kognitif. Contoh dari pendekatan behavioral adalah dengan mencari dukungan emosional dan sosial dari kerabat atau orang terdekat yang mereka merasa nyaman dan percaya, atau terlibat aktif dalam suatu aktivitas; seperti olahraga, berbelanja, jalan-jalan atau menonton televisi, dimana aktivitas itu bisa mengalihkan perhatian individu tersebut dari masalah yang sedang dihadapinya. Pendekatan kognitif meliputi bagaimana pandangan individu tersebut mengenai situasi yang menekan mereka

Seorang individu harus mampu mengelola keadaan emosinya dalam pembelajaran online dalam hal ini mahasiswa. Perasaan yang dirasakan dapat berupa cemas, sedih, bahagia, serta mengetahui penyebab munculnya perasaan tersebut. Mahasiswa juga harus memiliki strategi sendiri untuk mengatasi kecemasan yang dimilikinya. Mahasiswa akan mudah untuk menyusun strategi coping atau pengelolaan stress apabila mereka mengetahui faktor penyebabnya. Sebagaimana yang disampaikan oleh Benjet (2020) dalam penelitiannya mengungkapkan bahwa pentingnya kemampuan stress management mahasiswa agar dapat mengurangi stres bahkan depresi. Kemampuan ini juga dapat dilatih dengan program stress management melalui teknik kognitif, yang nantinya mahasiswa akan diajarkan atau dilatih mengelola pikiran negatifnya sehingga pikiran negatif tersebut tidak mendominasi kehidupan mereka. Selain itu didalam program juga diajarkan keterkaitan antara pikiran, perasaan, dan perilaku, sehingga penting untuk berlatih mengelola pikiran-pikiran yang muncul saat menghadapi berbagai kendala dimasa pembelajaran online.

Untuk mendukung mahasiswa dalam permasalahan terkait dengan tingkat stress dalam

Dipublikasikan Oleh : 
pembelajaran online maka universitas diharapkan ikut andil turut serta mengatasi tekanan psikologis dengan program diskusi cerita untuk saling menguatkan atau jadi sarana dalam bertukar pikiran, selain itu juga dapat menyediakan program konseling. Kesadaran pihak universitas juga penting dalam coping strategy yang terbatas pada mahasiswa yang tinggal sendiri tanpa orangtua dan keluarga yang harusnya mendapatkan perhatian yang lebih dimasa pandemi seperti sekarang (Nurunnabi et al, 2020).

\section{PENUTUP}

Berdasarkan hasil telaah berbagai jurnal ilmiah dapat disimpulkan bahwa pandemi covid19 berdampak pada bidang pendidikan khususnya proses belajar mengajar dengan diterapkannya pembelajaran online yang membuat mahasiswa mengalami stress akademik. Agar mahasiswa dapat meminimalisir dampak negatif yang timbul akibat stress akademik, mereka harusnya mampu melakukan copping stress.

Pengelolaan stress akademik melalui coping stress diharapkan agar mahasiswa lebih peduli dan sadar sehingga harapannya dapat mengurangi tekanan psikologis dalam menghadapi pembelajaran online dimasa pandemi covid-19.

\section{REFERENSI}

Agustiningsih, N. (2019). Gambaran Stress Akademik dan Strategi Koping Pada Mahasiswa Keperawatan. Jurnal Ners Dan Kebidanan (Journal of Ners and Midwifery), 6 (2), 241-250.

Aji, R. H. S. (2020). Dampak Covid-19 pada Pendidikan di Indonesia: Sekolah, Keterampilan, dan Proses Pembelajaran. Salam: Jurnal Sosial dan Budaya Syar-i, 7(5), 395-402

Amany D, Desire A. (2020) Pembelajaran Interaktif berbasis Gamifikasi guna Mendukung Program WFH pada saat Pandemic COVID-19. ADI Bisnis Digit Interdisiplin J [Internet]. 2020;48-55. Available from: https://adijournal.org/index.php/abdi/articl e/vie w/116

Barseli, M., \& Ifdil, I. (2017). Konsep Stres Akademik Siswa. Jurnal Konseling dan Pendidikan, 5(3), 143-148.

Benjet C (2020) Stress management interventions for college students in the context of the covid-19 pandemic.
Clinical Psychology Science and practice. DOI: $10.1111 / \mathrm{cpsp} .12353$.

Charismiadji, Indra. (2020). Mengelola Pembelajaran Daring yang Efektif, Base Learning Medical Curiculum. Medical Education, 2004 (38), 482-91.

Ciccarelli, S. K. (2015). Psychology 3ed.USA: Pearson.

Eryanti Fachrosi. (2012). Perbedaan Stres Akademik antara Kelompok Siswa Minoritas dengan Mayoritas di SMP WR. Supratman 2 Medan. Skripsi (tidak diterbitkan). USU Medan.

Fitriasari, A., Septianingrum, Y., Budury, S., Khamida, K. (2020). Stres pembelajaran Online Berhubungan Dengan Strategi Koping Mahasiswa Selama Pandemi Covid-19. Jurnal Keperawatan, 12(4), 985-992.

Goff.A.M. (2011). Stressor, academic performance, and learned resourcefulness in baccalaureate nursing students. International Journal of Nursing Education Scholarship, 8,923-1548.

Maia, Berta Rodrigues And Dias, Paulo César. (2020). Anxiety, depression and stres in university students: the impact of COVID-19. Estud. psicol. (Campinas) [online]. vol.37.

Nurunnabi M, Hossain SFA, Chinna K, et al. (2020) Coping Strategies of Students for Anxiety during the COVID-19 in China : a cross sectional study. figshare. Dataset

Purwati, S. (2012). Tingkat Stres Akademik Pada Mahasiswa Reguler Angkatan 2010 Fakultas Ilmu Keperawatan Universitas Indonesia. Skripsi. Depok: Universitas Indonesia.

Safaria, T. dan Saputra, N. E. (2009). Manajemen emosi: Sebuah panduan cerdas bagaimana mengelola emosi positif dalam hidup anda. Jakarta: Bumi Aksara.

Sarafino,E.P.,Smith,T.W. (2011). Health Psychology: Biopsychosocial Interactions (7TH Edition). USA: John Willey \& Sons, INC.

Sari D. (2020). Peran Adaptif Tiga Universitas di Jabodetabek dalam Menghadapi Sistem Belajar Online Selama Pandemi COVID 19. Prosiding Seminar Nasional Hardiknas. 1(1), 25-32.

Simbolon, I. (2015). Gejala Stres Akademis Mahasiswa Keperawatan Akibat Sistem Belajar Blok Di Fakultas Ilmu Keperawatan X Bandung. Jurnal 
Amallia Putri, Yuline

Jurnal Bimbingan dan Konseling Ar-Rahman

Volume 7, Nomor 2, Tahun 2021

e-ISSN 2477-6300

Skolastik Keperawatan. 1(1). Januari-Juni 2015.

Teguh, R, Adji, F.F, Wilentine, V, Usup, H\& Sahay, A.S. (2020).Dampak psikologis pandemic Covid - 19 terhadap mahasiswa di Kalimantan Tengah. Jurnal. DOI: 10.13140/RG.2.2.26837.04321

Wahyuni, N. E. (2017). Mengelola Stres Dengan Pendekatan Cognitive Behavior Modification. (Studi Eksperimen Pada Mahasiswa Baru Pendidikan Agama Islam (Pai) Fakultas Ilmu Tarbiyah \& Keguruan Uin Maliki Malang). Jurnal Tadrib, 3(1), Juni 2017.

Dipublikasikan Oleh : 